Acta Universitatis Nicolai Copernici • Pedagogika XXXVI/2/2018

Nauki Humanistyczno-Społeczne • Zeszyt 446

DOI: http://dx.doi.org/10.12775/AUNC_PED.2018.024

\author{
Anita Kotlenga \\ Uniwersytet Mikołaja Kopernika w Toruniu \\ ORCID: 0000-0002-7538-6089
}

\title{
Sprawozdanie z V Międzynarodowej Konferencji Naukowej \\ ZA KURTYNĄ RESOCJALIZACJI \\ Perspektywy RozWoju PedAgogiki ResocjalizacyjneJ \\ (Toruń, 2 kwietnia 2018 r.)
}

W Collegium Humanisticum 20 kwietnia 2018 roku odbyła się V jubileuszowa Międzynarodowa Konferencja Naukowa Za kurtyna resocjalizacji. Perspektywy rozwoju pedagogiki resocjalizacyjnej. Idea konferencji oscylowała wokół szeroko rozumianej pedagogiki resocjalizacyjnej. Konferencja od wielu lat staje się miejscem wymiany doświadczeń na gruncie zarówno akademickim, jak i instytucjonalnym, w tym roku swoją obecnością zaszczycili nas goście z ośrodków zagranicznych: Alexia-Sandy Gaillard z Francji, Robert Cotterell z Wielkiej Brytanii oraz Yevgen Barash, Olena Sokalska i Liudmyla Dubchak z Ukrainy. Swoją obecnością zaszczycili nas także przedstawiciele instytucji resocjalizacyjnych, między innymi płk Andrzej Leńczuk reprezentujący Dyrektora Generalnego Służby Więziennej oraz płk Jacek Gościak, Dyrektor Okręgowy Służby Więziennej w Bydgoszczy. W konferencji uczestniczyli prelegenci z 17 ośrodków akademickich w Polsce: Uniwersytetu Łódzkiego, Uniwersytetu Adama Mickiewicza w Poznaniu, Uniwersytetu Gdańskiego, Uniwersytetu Warszawskiego, Uniwersytetu Zielonogórskiego, Akademii Techniczno-Humanistycz- 
nej w Bielsku-Białej, Uniwersytetu Kardynała Stefana Wyszyńskiego w Warszawie, Uniwersytetu Warmińsko-Mazurskiego w Olsztynie, Akademii im. J. Długosza w Częstochowie, Uniwersytetu Wrocławskiego, Katolickiego Uniwersytetu Lubelskiego, Uniwersytetu Kazimierza Wielkiego w Bydgoszczy, Uniwersytetu Opolskiego, Akademii Ignatianum w Krakowie, Wielkopolskiej Wyższej Szkoły Społeczno-Ekonomicznej w Środzie Wielkopolskiej, Dolnośląskiej Szkoły Wyższej we Wrocławiu oraz Uniwersytetu Szczecińskiego. Liczba ośrodków partycypujących w wydarzeniu wskazuje na wysokie zainteresowanie niniejszą konferencją, jednak jej dodatkowymi atutami stają się wpisane już w charakter konferencji i cieszące się dużym zainteresowaniem Debata probacyjno-penitencjarna poprzedzająca konferencję oraz warsztaty szkoleniowe przygotowane przez praktyków, a także doktorantów i studentów Uniwersytetu Mikołaja Kopernika w Toruniu.

Otwarcia konferencji dokonała dr hab. Małgorzata H. Kowalczyk, prof. UMK, jednocześnie pomysłodawczyni i przewodnicząca komitetu organizacyjnego konferencji, gości przywitali prof. zw. dr hab. Beata Przyborowska, Prorektor ds. kształcenia Uniwersytetu Mikołaja Kopernika w Toruniu oraz Dziekan Wydziału Nauk Pedagogicznych UMK, dr hab. Piotr Petrykowski, prof. UMK. Przemowę wygłosili w imieniu Dyrektora Generalnego Służby Więziennej płk Andrzej Leńczuk oraz Dyrektor Okręgowy Służby Więziennej w Bydgoszczy płk Jacek Gościak. Dr hab. Małgorzata H. Kowalczyk, prof. UMK podczas konferencji została uhonorowana Medalem za Zasługi w Pracy Penitencjarnej, który przyznał Minister Sprawiedliwości Zbigniew Ziobro. Niniejszy medal wręczył płk Jacek Gościak, Dyrektor Okręgowy Służby Więziennej w Bydgoszczy, który podczas przemowy podkreślił wkład pracy, zaangażowanie oraz wieloletnią współpracę ze Służbą Więzienną dr hab. Małgorzaty H. Kowalczyk, prof. UMK. Uhonorowanie Pani Profesor wywołało szereg gratulacji od uczestników konferencji oraz gromkie brawa, inicjując jednocześnie pierwsze prelekcje. Wystąpienia w sekcji plenarnej moderowała prof. zw. dr hab. Beata Pastwa-Wojciechowska oraz prof. zw. dr hab. Piotr Chomczyński, pierwszym prelegentem był dr Yevgen Barash, prezentujący temat Roli i znaczenia religii $w$ resocjalizacji skazanych na Ukrainie (Role and importance of religion in the convicts' resocialisation in Ukraine), później referat wygło- 
siła dr Olena Sokalska prezentująca temat Resocjalizacji w ukraińskim dyskursie penologicznym (Resocialization in the Ukrainian Penological Discourse). Następny referat został wygłoszony przez prof. dr hab. Beatę Pastwę-Wojciechowską, która zaprezentowała temat Drogi i bezdroża resocjalizacji, czyli pomiędzy skutecznością, bezradnościa a pesymizmem; w swoim wystąpieniu Pani Profesor podkreśliła między innymi istotę i wagę procesu diagnozowania, wskazując na narzędzia psychologiczne, m.in. HCR20, narzędzie pomocne w Ocenie Ryzyka Przemocy, koncentrujące się na $\mathrm{H}$ - czynnikach w przeszłości jednostki diagnozowanej (problemy z przemocą, zachowania antyspołeczne, problemy z zatrudnieniem, problemy w relacjach, zażywanie substancji psychoaktywnych itp.), C - problemy z wglądem (problemy ze sferą poznawczą, manifestowanie objawów zaburzeń psychicznych, problemy z leczeniem i nadzorem), R - czynniki ryzyka (problemy z bytem, z uzyskaniem świadczeń, z planami życiowymi i kapitałem (wsparciem) społecznym, przyszłe problemy z radzeniem sobie w sytuacjach trudnych, stresujących) ${ }^{1}$. W swoim referacie Pani Profesor odwoływała się także do profesjonalizmu osób udzielających pomocy, wskazując na ciągłe dokształcanie i rozwój zawodowy. W dalszej części konferencji wysłuchaliśmy referatu pt. Autostygmatyzacja wychowanków zakładów poprawczych jako jedna z barier reintegracji społecznej. Socjologiczna analiza zjawiska, autorstwa prof. zw. dr. hab. Piotra Chomczyńskiego, kolejnym prelegentem w tej części konferencji był dr hab. Maciej Muskała, prezentując temat: Kurator sądowy wobec nowych zadań $i$ zmian $w$ systemie resocjalizacji. Ostatni był referat autorstwa Alexii-Sand Gaillard pt. Międzyregionalny podziat - Ustawowa ochrona młodzieży (Interregional Division - Judicial Youth Protection). Autorka wskazała na praktyki stosowane $\mathrm{w}$ Lyonie w zakresie postępowania z młodzieżą niedostosowaną społecznie.

Tegoroczna konferencja w swojej idei stała się płaszczyzną do wymiany poglądów oraz dyskusji w zakresie kierunków rozwoju pedagogiki resocjalizacyjnej, w szczególności w płaszczyźnie prawnej, w perspektywie makro i mikrostrukturalnej oraz w odniesieniu do nowych rozwiązań w praktyce resocjalizacyjnej. Sesje panelowe podzielone

${ }^{1}$ http://www.ryzykoprzemocy.pl/hcr-20-v3 (dostęp: 15.10.2017). 
zostały na sześć obszarów tematycznych: perspektywy prawne i kryminologiczne uwarunkowania przestępczości, perspektywy rozwoju penitencjarystyki, perspektywy rozwoju probacji, perspektywy teoretyczno-praktyczne, nowe kierunki badań i pracy oraz perspektywy społeczne, ostatni panel obejmował przede wszystkim wystąpienia studentów oraz doktorantów, prezentujących wyniki prowadzonych badań bądź analizy teoretyczne określonych zjawisk społecznych.

Konferencję od lat już charakteryzuje możliwość wymiany poglądów i stanowisk, a także otwartość prelegentów na pytania osób zainteresowanych problematyką. Podczas tegorocznej edycji nie było inaczej, poświęcono czas na interesujące i rozwijające poznawczo dyskusje pomiędzy nauczycielami akademickimi oraz praktykami reprezentującymi ten sam obszar zainteresowań, ukazując tym samym różne perspektywy. Konferencja dobiegała końca, gdy moderatorzy: prof. dr hab. Mariusz Sztuka, dr hab. Piotr Chomczyński, prof. UŁ, dr hab. Agata Matysiak-Błaszczyk, dr Michał Szykut oraz mgr Agnieszka Bandura zaprezentowali na forum tematykę referatów prezentowanych podczas obrad $\mathrm{w}$ sekcji. Istota relacji profesorów oraz doktorantki ukazuje potrzebę kontynuowania organizacji niniejszej Konferencji, gdyż wszyscy prowadzący w wypowiedziach podkreślali wysoki poziom wypowiedzi w prezentowanych treściach, aktualność podejmowanej problematyki oraz wiedzę prelegentów z zakresu podstaw teoretycznych oraz instrumentarium badawczego stosowanego w badaniach. Po prezentacji obszarów tematycznych dr hab. Małgorzata H. Kowalczyk oficjalnie uznała V Międzynarodową Konferencję Za kurtyna resocjalizacji. Perspektywy rozwoju pedagogiki resocjalizacyjnej za zakończoną, dziękując za uczestnictwo w Konferencji.

Jubileuszowa V Międzynarodowa Konferencja Za kurtyną resocjalizacji ukazała, iż nie jest to tylko miejsce refleksji naukowej, ale także miejsce dzielenia się różnorodnymi praktykami. Szczególnie dużą grupą osób uczestniczących już od lat w konferencji są kuratorzy sądowi, wychowawcy z Zakładów Karnych i Poprawczych, a także kadra z instytucji resocjalizacyjnych dla nieletnich sprawców czynów karalnych, m.in. Młodzieżowych Ośrodków Wychowawczych - ich ciągła obecność staje się informacją zwrotną dla organizatorów o potrzebie kontynuowania tejże idei. 